\title{
CHARACTERIZATION OF COURTSHIP SOUNDS OF SPECIES OF THE SUBGROUP fasciola (DIPTERA, DROSOPHILIDAE, Drosophila repleta GROUP): INTERSPECIFIC AND INTERPOPULATIONAL ANALYSES
}

\author{
COSTA, C. T. A. and SENE, F. M. \\ Universidade de São Paulo, USP, Av. Bandeirantes, 3900, CEP 14049-900, Departamento de \\ Genética da Faculdade de Medicina de Ribeirão Preto, Ribeirão Preto, SP, Brazil \\ Correspondence to: Fábio Melo Sene, Av. Bandeirantes, 3900, CEP 14049-900, \\ Depto. de Genética da Faculdade de Medicina de Ribeirão Preto, \\ Ribeirão Preto, SP, Brazil, e-mail: famesene@usp.br \\ Received September 20, 2001 - Accepted November 21, 2001 - Distributed November 30, 2002
}

(With 8 figures)

\begin{abstract}
The aim of this work was to characterize the male courtship song pattern of various species of the fasciola subgroup and to determine the level of variation both within and among species. The parameters analyzed were intrapulse interval (PI), interpulse interval (IPI), and intrapulse frequency (IF). Six different species were analyzed: D. coroica (three populations), D. ellisoni, D. fascioloides, $D$. moju, D. onca, and D. rosinae (one population each). There were significant differences among the six species for these three courtship song parameters. The IPI was the most variable parameter among these species, suggesting that this parameter is important for female discrimination. Four different hypotheses could explain this variation: 1 . different selection pressures with absence of flow gene; 2. intraspecific sexual selection; 3. sympatric effects on song evolution; and 4. genetic drift. The PI was the only parameter that was significantly different among the three population of $D$. coroica. Low variability among populations within the same species was already observed for other subgroups and could be explained by the following hypotheses: strong selection acting on the song parameters, gene flow, or recent colonization from a common source. Additional studies of the courtship song of other species of the fasciola subgroup, as well as for other subgroups of the repleta group, and studies, using molecular makers, that focus on the genetic basis of the differences among these species in courtship song would allow us to evaluate the association of courtship song and sexual isolation in these species, and would also help us to understand the evolution of these behavioural differences.
\end{abstract}

Key words: drosophila, fasciola subgroup, courtship song, evolution, behavior.

\section{RESUMO}

Caracterização do som da corte sexual de espécies do subgrupo fasciola (Diptera, Drosophilidae, grupo repleta): análises interespecíficas e interpopulacionais

Com o objetivo inicial de caracterizar o padrão sonoro da corte sexual de machos de diferentes espécies do subgrupo fasciola e determinar a possível ocorrência de variação e o grau de diferenciação tanto inter como intraespecífico, foram analisados os parâmetros intervalo intrapulso (PI), intervalo interpulso (IPI) e frequiência intrapulso (IF) de 6 diferentes espécies: D. coroica, D. ellisoni, D. fascioloides, $D$. moju, D. onca e $D$. rosinae, e três populações de diferentes origens geográficas da espécie $D$. corioca. Comparações estatísticas entre as 6 espécies mostraram diferenças significativas em relação aos 3 parâmetros analisados. O IPI foi o parâmetro de maior diferenciação interespecífica, mostrando ser importante durante o reconhecimento da fêmea. As hipóteses que podem explicar essas diferenças são: 1. pressões seletivas diferentes com ausência de fluxo gênico, 2. seleção sexual intraespecífica; 
3. efeito de simpatria; e 4. deriva genética. As análises realizadas entre as 3 populações da espécie D. coroica mostraram diferenças estatísticas somente em relação ao PI. Essa baixa variabilidade entre populações de uma mesma espécie também já foi encontrada em outros subgrupos e pode ser explicada pelas seguintes hipóteses: forte seleção sobre os parâmetros sonoros, ocorrência de fluxo gênico entre as populações ou colonizações recentes a partir de um ancestral comum. Estudos da corte sonora de outras espécies do subgrupo fasciola e mesmo de espécies de outros subgrupos do grupo repleta, e também estudos relacionados à base genética das diferenças sonoras entre as espécies, utilizando marcadores moleculares, ajudariam a avaliar a relação dos parâmetros sonoros com o processo de isolamento sexual e também a entender a evolução dessas diferenças comportamentais.

Palavras-chave: drosophila, subgrupo fasciola, corte sonora, evolução, comportamento.

\section{INTRODUCTION}

\section{Courtship sounds}

Courtship behavior of flies of the genus

Drosophila is important for species recognition. After Shorey (1962) showed that D. melanogaster males emitted sounds during sexual courtship, many studies were made with the various groups and subgroups of the genus Drosophila, describing the specific nature of the sound types. These studies have provided evidence that sound has a function both as a sexual stimulant and in sexual isolation. These sounds vary significantly among the various species of the affinis (Chang \& Miller, 1978), melanogaster (Cowling \& Burnet, 1981), virilis (Hoikkala et al., 1982; Hoikkala \& Isoherranen, 1997), mercatorum (Ikeda \& Maruo, 1982), repleta (Ewing \& Miyan, 1986), auraria (Tomaru \& Oguma, 1994), planitibia (Hoikkala et al., 1994), willistoni (Ritchie \& Gleason, 1995), quinaria (Neems et al., 1997), and obscura (Noor \& Aquadro, 1998) groups.

The interspecific differences in Drosophila courtship sounds are characterized by one or more sound parameters such as: interpulse interval (IPI) which is the time from the beginning of one pulse to the beginning of the next; intrapulse interval (PI) which is the pulse duration; intrapulse frequency (IF) which is acoustically the strongest frequency within the pulse; number of pulses per series; and duration of each interval within a series (Hoikkala \& Lumme, 1987; Wheeler et al., 1988). Although it has not been firmly established which sound parameters confer specificity, there is evidence that IPI is important. According to Ritchie \& Kyriacou (1996), the IPI of Drosophila courtship sounds varies very little within natural populations and is important for male reproductive success.
However, it is clear that many Drosophila species produce complex sounds with various characteristics, one or more of which can be of value in identifying species. This specificity in Drosophila courtship sounds can be explained by selection for discrimination between species (Tomaru \& Oguma, 1994) of the different types of sounds, which could have evolved through intraspecific sexual selection (Ritchie \& Gleason, 1995). Also, the different types of sounds found in the various Drosophila species could simply reflect phylogenetic divergences.

\section{The fasciola subgroup}

The species of the subgroup fasciola are found in humid forests, principally those of Central and South America and the Caribbean islands. In Brazil they have been collected from the Atlantic rain forest, as well as from forests in the states of São Paulo, Paraná, Mato Grosso do Sul, and Bahia (Vilela, 1983; Vilela et al., 1983; Tidon-Sklorz $\&$ Sene, 1992).

Most work on this subgroup has been cytological and was done in the beginning of the 60 s, showing that the species in this group differ from all of the rest of the repleta group in having the homozygotic inversions: $2 \mathrm{o}^{2}, 2 \mathrm{e}^{3}$, and $2 \mathrm{l}^{3}$. Wasserman (1982) proposed a common ancestry for the subgroups fasciola and mulleri, because they have the $3 \mathrm{c}$ inversion in common. Recently however, Diniz (1998) showed that the 3c inversion of the subgroup fasciola is different from that found in the subgroup mulleri and proposed that the subgroup fasciola was derived directly from primitive I, and can no longer be considered linked to the mulleri subgroup. Kuhn et al. (1995) made a karyotypic study of some species of the fasciola subgroup and found interspecific variation in the size of the microchromosome and in chromosome numbers. 
According to Wasserman (1992), the fasciola subgroup consists of nine species: $D$. pictilis and $D$. pictura, forming the pictilis complex; D. paraguttata; $D$. mojuoides and D. moju, forming the moju complex; and D. fulvalineata, D. fasciola, D. coroica, and $D$. fascioloides which are not found in any complex. Vilela (1983), studying the morphology of male genitalia, determined that the species $D$. fascioloides studied by Wasserman (1962) actually did not belong to this species, and renamed it $D$. ellisoni. He also added the species D. linearepleta and $D$. onca to the subgroup fasciola and described D. carolinae, D. hermionae, D. ivai, D. querubimae, $D$. rosinae, and $D$. sene $i$ as new species, increasing to 18 the number of species in this subgroup.

In this work we describe the courtship sound patterns of six species of the subgroup fasciola: $D$. ellisoni, D. fascioloides, D. moju, D. onca, D. rosinae, and $D$. coroica. Besides the interspecific analyses, we also examined the differences in the sound patterns of three different populations of $D$. coroica.

\section{MATERIALS AND METHODS}

\section{Establishment and maintenance of isolines}

Isolines were produced from individual females already mated in the wild. These isolines were identified through morphological analysis of the genitalia of F1 males (Vilela, 1983). Third instar larvae of the subgroup fasciola normally attempt to crawl out of the culture vial. To avoid this problem, the culture vials were opened and placed on moist sand within plastic bottles so that the larvae could pupate in the sand. Ecloded flies were removed with an aspirator and transferred to vials filled with culture media, where they matured, mated, and laid eggs, reinitiating the cycle.

\section{Sound recordings}

Recently ecloded virgin flies were isolated in $35 \mathrm{ml}$ culture vials and left for 7-10 days to allow time for sexual maturation. Subsequently, a male and a female of the same lineage were introduced into a sound recording chamber described by Sene \& Manfrin (1998). To record the sound, the chamber containing the pair of flies was placed on the diaphragm of an ultrasensitive microphone, as described by Manfrin et al. (1997). The flies were observed for a maximum of 10 minutes, or until mating. All recordings were made at $25 \pm 1^{\circ} \mathrm{C}$.

\section{Sound analysis}

The electromagnetic signals of the analogical recordings were converted into digital signals at a frequency of $5 \mathrm{KHz}$, with an analogical-digital converter circuit CAD 12/36-60 k (Lynx) and the AqDADOS 4 (Lynx) program.

The courtship sound patterns of six different species of the subgroup fasciola are described in Table 1 . The sound patterns of $D$. coroica males from three different locations were also analyzed in order to study interpopulational differences.

TABLE 1

Locality, habitat and collection date of the different isolines of the species of the subgroup fasciola used in this study.

\begin{tabular}{|l|c|c|c|c|}
\hline Isoline & Species & Locality & Habitat & Collection date \\
\hline D83M1 & D. ellisoni & São Sebastião-SP & Atlantic rain forest & February-1992 \\
\hline D86N17 & D. fascioloides & Nova Friburgo-RJ & Continental forest & March-1992 \\
\hline F34M2 & D. moju & Panamá & $?$ & August-1989 \\
\hline J16CM1 & D. onca & Tibaji-PR & Continental forest & November-1997 \\
\hline D63M1 & D. rosinae & Mucugê-BA & Caatinga & July-1990 \\
\hline D96N74 & D. coroica & São Carlos-SP & Continental forest & August-1993 \\
\hline D88M1 & D. coroica & Sertãozinho-SP & Continental forest & September-1992 \\
\hline J7C1 & D. coroica & Itirapina-SP & Continental forest & November-1997 \\
\hline
\end{tabular}


The parameters used for comparative studies of the sound patterns were the intrapulse interval (PI), interpulse interval (IPI) and intrapulse frequency (IF). The PI and IPI values were obtained directly from the figures. The IFs were obtained with the help of MATLAB software (MathWorks, Inc.) using Fast Fourier Transforms (FFT). This analysis breaks down the sound signal into a series of waves (sines and cosines) of different frequencies and amplitudes. The IF of a sound is defined as the frequency of the highest amplitude wave in the sound signal.

The FFT can analyze sounds containing thousands of points per millisecond, but maximum analysis efficiency is obtained by restricting the number of points to base two potentials. For this reason, all intervals used for analysis of IF were selected so that they had a number of points equal to base two potentials. Therefore, intervals of 64 points were used for $D$. moju; 128 points for $D$. rosinae and D. coroica; 256 points for D. ellissoni; and 512 points for $D$. onca and D. fascioloides.

Ten measures were made of the parameters PI, IPI, and IF for each of 10 males from each of the isolines.

\section{Statistical analysis}

The lines described in Table 1 were analyzed with the objective of investigating interspecific differences. Isoline D96N74 was chosen as representative of $D$. coroica. The three lines (D96N74, D88M1, and J7C1) of D. coroica were tested separately for interpopulational differences. The values of the parameters intrapulse interval (PI), interpulse interval (IPI), and intrapulse frequency (IF) were analyzed separately by variance analysis (ONE-WAY ANOVA) at a 0.05 significance level.

\section{RESULTS}

Figs. 1 to 6 show the basic sonograms of the various species analyzed. Isoline D96N74 was chosen to represent the species $D$. coroica. These sonograms and the analysis of sound pulses permit a division of the courtship sounds into three distinct groups: 1. courtship sounds of the species D. onca, D. fascioloides, and D. ellisoni, in which each sound sequence is composed of a sequence of short pulses, followed by a trill, similar to that found in some species of the subgroup planitibia, denominated by Hoikkala et al. (1994) as phrase song. In the species $D$. fascioloides and $D$. onca, the sequence of pulses is made up of four pulses, followed by a relatively long trill, while in $D$. ellisoni, there are only two pulses, followed by a shorter trill; 2. the type typical of the sonogram of $D$. rosinae, with a courtship sound formed by simple but duplicated pulses, a pattern also observed by Ewing \& Miyan (1986) in some species of the repleta group; 3 . a type based on the courtship sounds of the species D. moju and $D$. coroica, with short pulses in sequence, similar to the pulse song of D. melanogaster (Schilcher, 1976) and sound A of D. mercatorum (Ikeda \& Maruo, 1982; Manfrin et al, 1997).

The sonograms of each of the species analyzed were a sequence of one type of sound pulse. This finding is different from those of studies made on the species D. melanogaster (Schilcher, 1976), D. mercatorum (Ikeda \& Maruo, 1982; Manfrin et al., 1997), and some species of the subgroup repleta (Ewing \& Miyan, 1986), in which two different types of sounds were found.

Table 2 show the mean values for PI (intrapulse interval), IPI (interpulse interval), and IF (intrapulse frequency) of the isolines described in Table 1. A comparison of the standard deviations ( \pm sd) among the various species shows that $D$. ellisoni and $D$. fascioloides have the least variation for all three parameters: PI $(27.470 \pm 2.73$ and $69.859 \pm 6.12)$, IPI $(97.473 \pm 5.76$ and $125.757 \pm$ $7.87)$, and IF $(251.358 \pm 19.36$ and $362.901 \pm$ 17.04), indicating that the courtship sounds of these species are uniform with little intraspecific variation. On the other hand, D. onca had considerable variation in PI (93.662 \pm 31.44$)$ and IPI (508.091 \pm 73.06$)$ and moderately high variation in IF $(289.260 \pm$ 32.71) when compared to the other species, indicating that the differences in PI and IPI, though large, were not sufficient to significantly alter the pulse wave form. The standard deviations were relatively low for PI $(7.363 \pm 7.36$ and $14.673 \pm$ $1.98)$ and IPI $(50.859 \pm 5.47$ and $72.340 \pm 5.68)$ in $D$. тоju and D. rosinae, but the IF values were relatively high $(412.501 \pm 55.63$ and $306.624 \pm$ 57.80). In this case, though the pulse duration and the time from one pulse to the next were relatively uniform within each of these species, the sound pulse waveform varied considerably. 

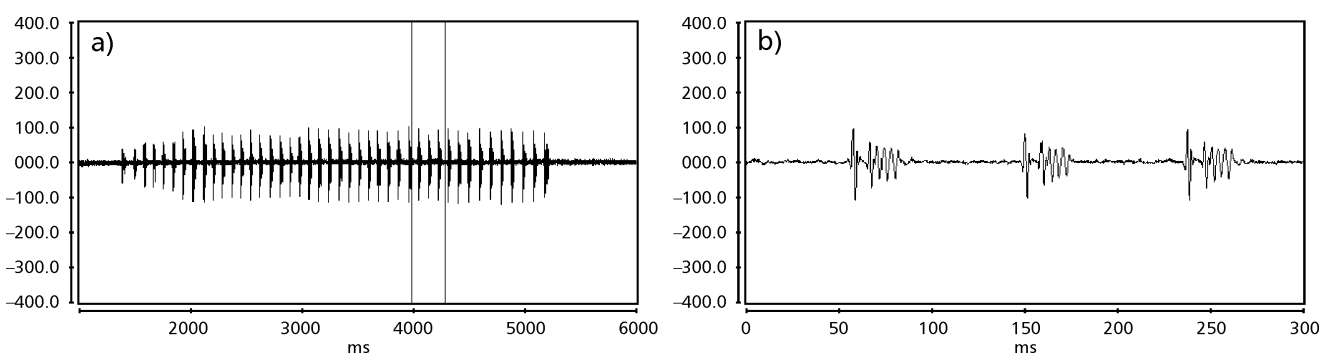

Fig. 1 - Courtship sound pattern of D. ellisoni (D83M1). (a) 5 second interval, (b) 300 millisecond interval. The X-axis represents the time in milliseconds and the Y-axis indicates arbitrary (relative) intensity units.
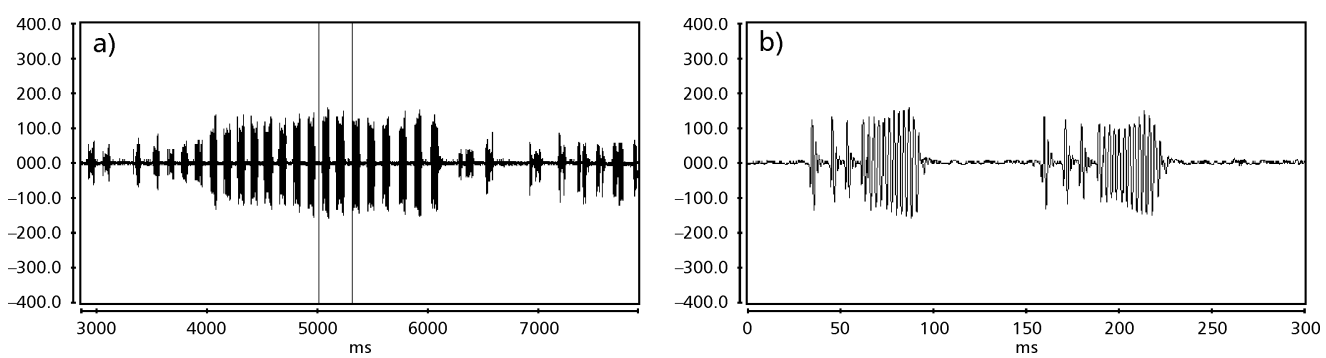

Fig. 2 - Courtship sound pattern of D. fascioloides (D86N17). (a) 5 second interval, (b) 300 millisecond interval. The Xaxis represents the time in milliseconds and the Y-axis indicates arbitrary (relative) intensity units.
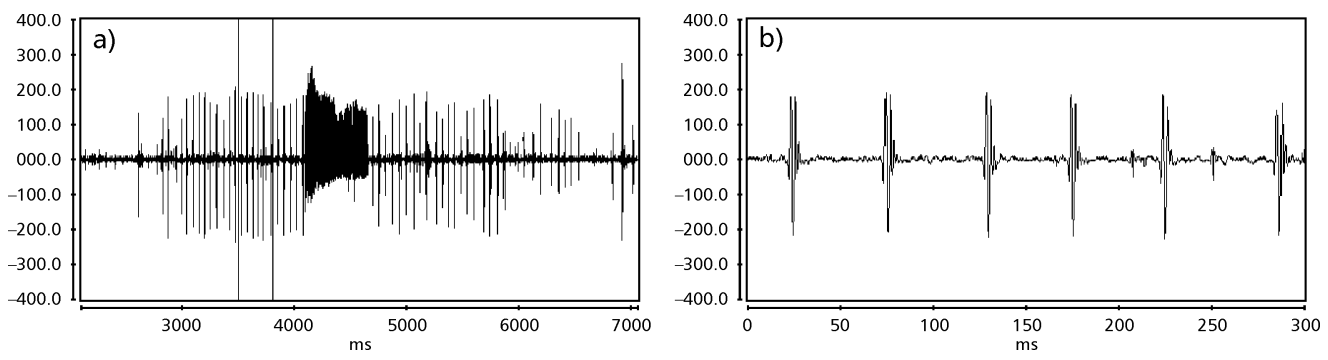

Fig. 3 - Courtship sound pattern of D. moju (F34M2). (a) 5 second interval, (b) 300 millisecond interval. The X-axis represents the time in milliseconds and the Y-axis indicates arbitrary (relative) intensity units.
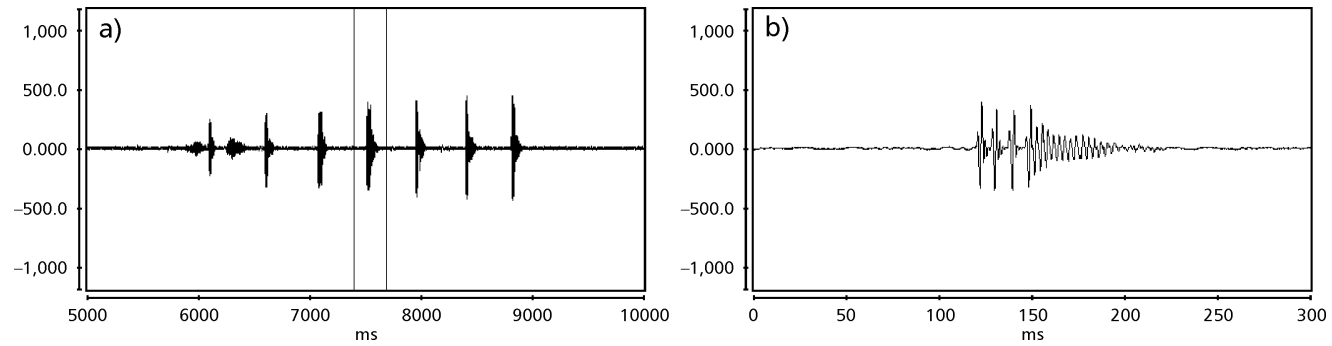

Fig. 4 - Courtship sound pattern of D. onca (J16CM1). (a) 5 second interval, (b) 300 millisecond interval. The X-axis represents the time in milliseconds and the Y-axis indicates arbitrary (relative) intensity units. 

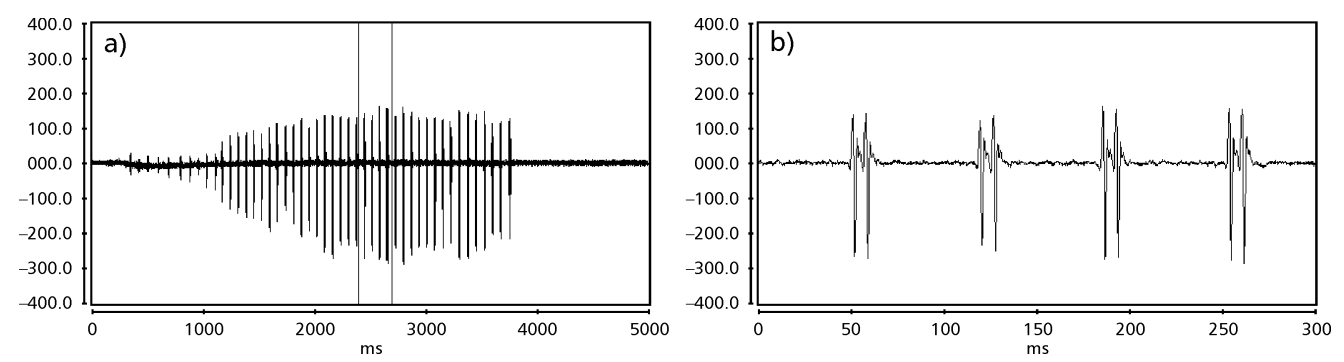

Fig. 5 - Courtship sound pattern of D. rosinae (D63M1). (a) 5 second interval, (b) 300 millisecond interval. The X-axis represents the time in milliseconds and the Y-axis indicates arbitrary (relative) intensity units.
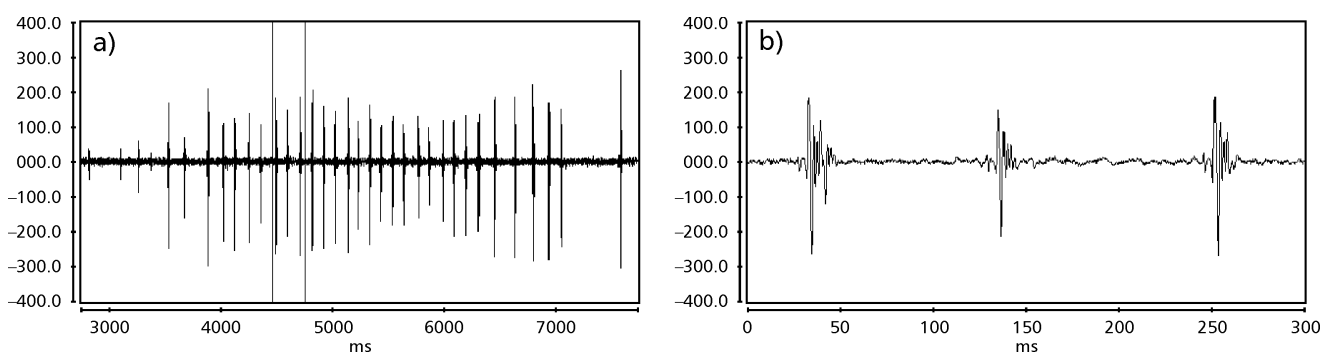

Fig. 6 - Courtship sound pattern of D. coroica (D96N74). (a) 5 second interval, (b) 300 millisecond interval. The-X axis represents the time in milliseconds and the Y-axis indicates arbitrary (relative) intensity units.

TABLE 2

Mean and standard deviation for the parameters intrapulse interval (PI), interpulse interval (IPI) and intrapulse frequency (IF) of the courtship sound of $\mathbf{1 0}$ males from each of the lines that were analyzed. The values for each individual included 10 measurements for each parameter.

\begin{tabular}{|c|c|c|c|}
\hline Species (isoline) & $\mathrm{PI}(\mathrm{ms}) \pm \mathrm{sd}$ & IPI $(\mathrm{ms}) \pm \mathrm{sd}$ & IF $(\mathbf{H z}) \pm \mathrm{sd}$ \\
\hline D. ellisoni (D83M1) & $27.470 \pm 2.728$ & $97.473 \pm 5.763$ & $251.358 \pm 19.358$ \\
\hline D. fascioloides (D86N17) & $69.859 \pm 6.116$ & $125.757 \pm 7.871$ & $362.901 \pm 17.037$ \\
\hline D. тоји (F34M2) & $7.363 \pm 1.444$ & $50.859 \pm 5.473$ & $412.501 \pm 55.633$ \\
\hline D. onca (J16CM1) & $93.662 \pm 31.436$ & $508.091 \pm 73.056$ & $289.260 \pm 32.711$ \\
\hline D. rosinae (D63M1) & $14.673 \pm 1.979$ & $72.340 \pm 5.679$ & $306.624 \pm 57.804$ \\
\hline D. coroica (D96N74) & $17.271 \pm 2.178$ & $101.303 \pm 12.604$ & $318.353 \pm 56.192$ \\
\hline D. coroica (D88M1) & $20.256 \pm 3.900$ & $109.101 \pm 17.317$ & $305.459 \pm 61.180$ \\
\hline D. coroica $(\mathrm{J} 7 \mathrm{C} 1)$ & $22.819 \pm 4.382$ & $99.050 \pm 18.576$ & $314.364 \pm 77.703$ \\
\hline
\end{tabular}


There was relatively little intrapopulational variation in the PIs of D. coroica lines D96N74, D88M1, and J7C1 (17.271 $\pm 2.18,20.256 \pm 3.90$ and $22.819 \pm 4.38$, respectively), intermediate variability in IPI $(101.303 \pm 12.60,109.101 \pm$ 17.32 and $99.050 \pm 18.58)$, and high variability in IF $(318.353 \pm 56.19,305.459 \pm 61.18$ and $314.364 \pm 77.70)$, indicating that even with low intrapopulational variation in the length of the sound pulse, there was considerable variation in the sound pulse waveform.

When mean values for parameters PI and IPI were compared, differences among the species of the subgroup fasciola could be found for at least one of these parameters. These differences in the courtship sounds can be seen in Fig. 7, in which the values for these two parameters are represented in the form of ellipses, which include $75 \%$ of the values for parameters PI and IPI. Significant differences were found in the PI (ANOVA, $\mathrm{F}_{5,48}=$ 124.98, $\mathrm{p}<0.001$ ) and IPI (ANOVA, $\mathrm{F}_{5,48}=$ $949.35, \mathrm{p}<0.001)$ values among species. The interspecific differences in IF are shown in Fig. 8. Significant difference were also found in the IF values (ANOVA, $\mathrm{F}_{5,48}=23.40, \mathrm{p}<0.001$ ).

The three populations of $D$. coroica did differ significantly in the PI (ANOVA, $\mathrm{F}_{2,24}=8.75, \mathrm{p}<0.05$ ) but not in the IPI (ANOVA, $\mathrm{F}_{2,24}=1.72, \mathrm{p}>0.10$ ) and IF (ANOVA, $\mathrm{F}_{2,24}=0.15, \mathrm{p}>0.25$ ).

\section{DISCUSSION}

Hoikkala et al. (1994) in their analysis of the courtship sound of various species of the subgroup planitibia, discovered that it is common to find the same types of sounds in phylogenetically close species. Also, Hoikkala \& Kaneshiro (1993) observed that some closely related species in this subgroup, which are sympatric, use different types of sounds in courtship.

Noor \& Aquadro (1998) found significant differences in courtship sounds in two closely related species of the subgroup obscura: D. pseudoobscura and D. persimilis. Some experiments involving crosses between these two species indicated that females of D. pseudoobscura probably increased their discrimination against $D$. persimilis males in sympatric populations. This could have occurred through selection against the production of badly adapted hybrids, resulting in a courtship sound alteration in these sympatric populations.

Ewing \& Miyan (1986), working with species of the repleta group, found no relationship between a phylogeny based on cytological data and another made from sound data. Nevertheless, some of the characteristics that most of the species studied have in common and which are also found in species of other groups allow us to propose an ancestral courtship sound for the repleta group. This sound would have been composed of two distinct components: the initial sound $\mathrm{A}$, consisting of a maximum of 10 short and regular monocyclic pulses, with an interpulse interval of from 8 to 15 $\mathrm{ms}$; and sound B, composed of a series of regular and monocyclic pulses, but with a larger number of pulses and a longer interpulse interval at the end of courtship. During the evolution of the repleta group, some species would have lost sound $\mathrm{A}$, and others, sound B, and, in many, sound B would have become less regular and more complex.

Based on these suppositions and observing the sonograms obtained for the six species of the fasciola subgroup in this study, we can infer that in all of these species there was a loss of sound A, since the interpulse intervals are always much longer than $15 \mathrm{~ms}$. D. coroica has irregular pulses, with a mean interpulse interval of $101.3 \mathrm{~ms}$, while the courtship sounds of $D$. moju are made up of more regular pulses, with a mean interpulse interval of $50.9 \mathrm{~ms}$. D. rosinae has a sonogram made up of duplicated pulses, a sound type also found by Ewing \& Miyan (1986), with a mean interpulse interval of 72.3 ms. D. ellisoni, D. fascioloides, and D. onca have courtship sounds made up of polycyclic pulses, probably a result of a fusion of sounds A and B, with mean interpulse intervals of $97.4,125.7$, and $508.0 \mathrm{~ms}$, respectively. These similarities in the types of sounds in these three species are not closely correlated to cytological data, except for D. ellisoni and $D$. fascioloides which were placed near each other in a phylogeny based on cytological characters, they have two chromosome fusions in common: 2$4 \mathrm{~F}$ e 3-5F (Diniz, 1998). As is the case for morphological characters, a tendency for closely related species to share some sound parameters is expected. Nevertheless, even when the phylogenetic relationships among the species are known, the evolutionary tendencies based on sound characters have not been well established. 


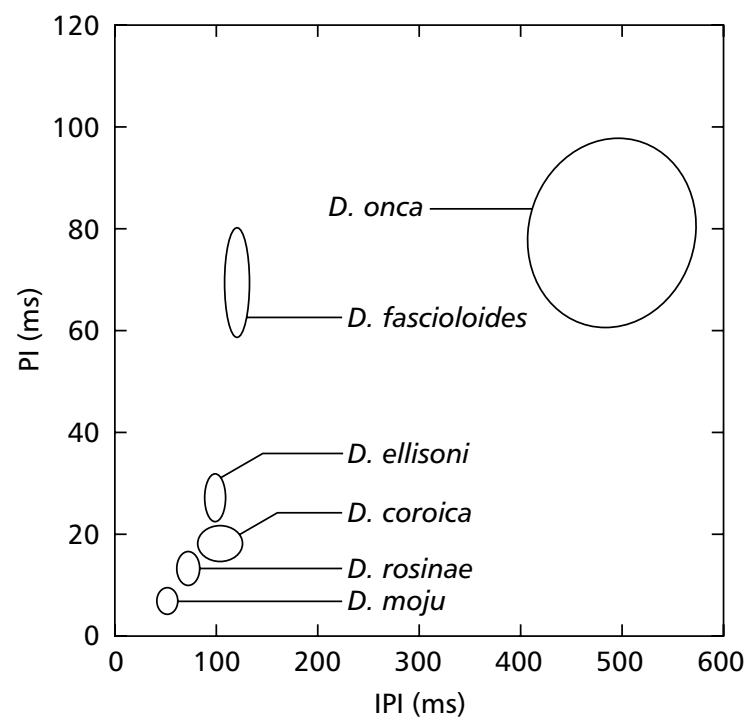

Fig. 7 - Representation of the ellipses that include $75 \%$ of the PI and IPI values of the six species of the subgroup fasciola that were analyzed: D. ellisoni (D83M1 - São Sebastião, SP), D. fascioloides (D86N17 - Nova Friburgo, RJ), D. moju (F34M2 - Panamá), D. onca (J16CM1 - Tibaji, PR), D. rosinae (D63M1 - Mucugê, BA) and D. coroica (D96N74 - São Carlos, SP).

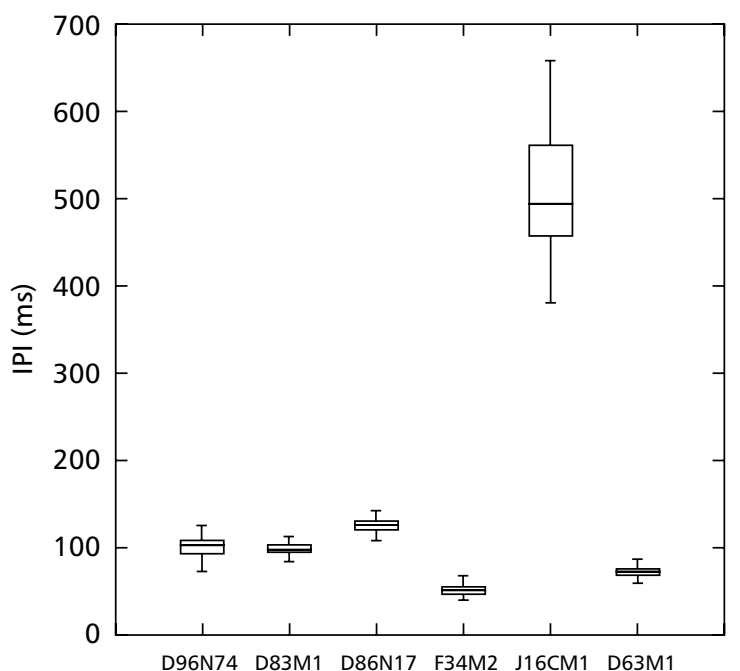

Fig. 8 - Distribution of the IFs of the six species of the subgroup fasciola that were analyzed: D96N74 (D. coroica - São Carlos, SP); D83M1 (D. ellisoni - São Sebastião, SP); D86N17 (D. fascioloides - Nova Friburgo, RJ); F34M2 (D. moju - Panamá); J16CM1 (D. onca - Tibaji, PR); D63M1 (D. rosinae - Mucugê, BA). The horizontal lines inside the boxes represent the medians. The boxes contain the values $25 \%$ above and below the median. The upper and lower portions contain the $25 \%$ highest and $25 \%$ lowest values, respectively. 
Even though courtship sound is not an example of circadian behavior, research has related this behavior to the expression of the gene period (per) located on the $\mathrm{X}$ chromosome and well characterized at the molecular level. Mutations in this gene can alter the circadian rhythm of Drosophila. A genetic analysis made by Konopka et al. (1996) showed that the sound rhythm of the interpulse interval is also affected by mutations in the gene per. Kyriacou \& Hall (1980) reported a rhythmic modulation of the interpulse interval with specific periods in D. melanogaster and $D$. simulans of 55 and 35 seconds respectively. These differences were shown to be related to some variations in the per gene. Mutations in this gene, that were initially studied by Konopka \& Benzer (1971) in an analysis of abnormal circadian rhythms, provoked corresponding effects in the interpulse interval rhythms of the courtship sounds. The mutation per $^{\text {Short }}\left(\mathrm{per}^{S}\right)$, with a circadian rhythm of about 19-20 hours, had a mean period of 41.5 seconds; mutation per $^{\text {Long }}\left(\right.$ per $^{L}$ ) whose circadian rhythm of 28-30 hours had a mean period of 82.1 seconds; and mutation per $^{0}$ had no interpulse interval rhythm.

In this research we found significant differences in the parameters intrapulse interval, interpulse interval, and intrapulse frequency in the fasciola species analyzed. Among these parameters, the interpulse interval was the one that differed most, with little superposition and little intraspecific variation, suggesting that this parameter could be part of a species recognition system. This high level of differentiation in the male sounds is consistent with the general consensus that courtship behavior can differ more than morphological characters or other characteristics in related species. However, it is impossible at the moment to know the direction of evolution of these different types of sounds in the fasciola subgroup. Genetic studies have shown that interspecific differences in interpulse intervals are frequently due to additive and polygenic factors. These differences can also be explained by adaptation to different environments in the absence of gene flow. It is known that there were alternating cycles between cold-dry and hot-humid in the Quartenary period. In a cold-dry climate cycle, vegetation adapted to the dry conditions expanded, while forest retracted. During the subsequent hothumid cycle the situation inverted (Ab' Saber,
1977; Vanzolini, 1981). It is believed that the flies followed these processes of forest reduction and expansion, which would result in long periods of geographic isolation during the cold-dry cycles and some areas of sympatry during the hot-humid cycles.

Though the interpulse interval can vary widely among different species of the genus Drosophila, generally this is not observed when populations of the same species are analyzed (Costa et al., 2000; Ritchie et al., 1994). The three analyzed populations of $D$. coroica had significant differences only in the intrapulse interval, with no differences in the interpulse interval and intrapulse frequency. It is possible that a strong selection pressure is acting on the interpulse interval and intrapulse frequency. This low variability could also occur if geographically distinct populations were genetically homogeneous due to constant gene flow, or if a common ancestor had recently colonized these populations. However, the PI data show that this is not the case.

Little is known about the genetic mechanisms involved in the speciation processes, however it is first necessary to understand the genetics and evolution of the mechanisms impeding gene flow. Sterile and unstable hybrids are considered strong barriers to gene flow, but these types of postzygotic mechanisms can result in high costs in the form of gametes and energy. Therefore, differences in courtship sounds can be an important isolating mechanism, as they would limit or prevent such losses (Welbergen et al., 1992). Analysis of these signals, which are important for mating success, is of considerable interest for evolutionary biology and knowledge of the architecture of sounds could help prove various models of sexual selection and speciation.

Acknowledgments - We thank N. M. Diniz, E. M. Moraes, M. H. Manfrin, P. R. R. Prado, S. G. Monteiro, G. C. S. Kuhn and P. R. Epifânio, for participating in different stages of the work. This work was part of the Ph.D. Thesis of C. T. A. Costa (Capes fellowship) and carried out in the Dept. of Genetics F. M. R. P. University of S. Paulo, supported by FAPESP, CNPq, FINEP, and USP.

\section{REFERENCES}

AB' SABER, A. N., 1977, Espaços ocupados pela expansão dos climas secos da América do Sul, por ocasião dos períodos glaciais quaternários. Paleoclimas, 3: 1-19. 
CHANG, H. C. \& MILlER, D. D., 1978, Courtship and mating sounds in species of the Drosophila affinis subgroup. Evolution, 32: 540-550.

COSTA, C. T. A., KUHN, G. C. S. \& SENE, F. M., 2000, Low courtship song variation in South and Southearn Brazilian populations of D. meridionalis (Diptera, Drosophilidae). Rev. Brasil. Biol., 60: 53-61.

COWLING, D. E. \& BURNET, B., 1981, Courtship songs and genetic control of the acoustic characteristics in sibling species of the Drosophila melanogaster subgroup. Anim. Behav., 29: 924-935.

DINIZ, N. M., 1998, Filogenia cromossômica de espécies do subgrupo fasciola do grupo repleta gênero Drosophila. Tese de Doutorado, Faculdade de Medicina de Ribeirão Preto da Universidade de São Paulo.

EWING, A. W. \& MIYAN, J. A., 1986, Sexual selection, sexual isolation and the evolution of song in the Drosophila repleta group of species. Anim. Behav., 34: 421-429.

HOIKKALA, A. \& LUMME, H., 1987, The genetic basis of the evolution of the male courtship sounds of the Drosophila virilis group. Evolution, 41: 827-845.

HOIKKALA, A. \& KANESHIRO, K. Y., 1993, Change in the signal-response sequence responsible for asymmetric isolation between Drosophila planitibia and D. silvestris. Proc. Natn,. Acad. Sci., 90: 5813-5817.

HOIKKALA, A. \& ISOHERRANEN, E., 1997, Variation and repeatability of courtship song characters among wildcaught and laboratory-reared Drosophila montana and D. littoralis males (Diptera-Drosophilidae). Jornal of Insect Behavior, 10: 193-202.

HOIKKALA, A., LAKOVAARA, S. \& ROMPPAINEN, E., 1982, Mating behaviour and male courtship sounds in the Drosophila virilis group. In: Lakovaara, S. (ed.), Advances in genetics, development and evolution of Drosophila. Plenum, New York.

HOIKKALA, A., KENNETH, Y. \& HOY, R. H., 1994, Courtship songs of the picture-winged Drosophila planitibia subgroup species. Anim. Behav., 47: 1363-1374.

IKEDA, H. \& MARUO, O., 1982, Directional selection for pulse repetition rate of the courtship sound and correlated responses occurring in several characters in Drosophila mercatorum. Jnp. J. Genet., 57: 241-258.

KONOPKA, R. J. \& BENZER, S., 1971, Clock mutants of Drosophila melanogaster. Proc. Natl. Acad. Sci., 68: 2112-2116.

KONOPKA, R. J., KYRIACOU, C. P. \& HALL, J. C., 1996, Mosaic analysis in the Drosophila CNS of circadian of courtship song rhythms affected by a period clock mutation. J. Neurogenet., 11: 117-140.

KUHN, G. C. S., DINIZ, N. M., ALVES, M. A. R. \& SENE, F. M., 1995, Constituição cariotípica de espécies do subgrupo fasciola do grupo repleta gênero Drosophila. Rev. Bras. Gen., 18 supplement: 282.
KYRIACOU, C. P. \& HALL, J. C., 1980, Circadian rhythm mutations in Drosophila melanogaster affect short-term fluctuations in the male's courtship song. Proc. Natl. Acad. Sci., 77: 6729-6733.

MANFRIN, M. H., PRADO, P. R. R. \& SENE, F. M., 1997, Analysis of sound components of sexual courtship of two subspecies of Drosophila mercatorum (Diptera, Drosophilidae). Rev. Brasil. Biol., 57: 349-355.

NEEMS, R. M., DOOHER, K., BUTLIN, R. K. \& SHORROCKS, B., 1997, Differences in male courtship song among the species of the quinaria group of Drosophila. Journal of Insect Behavior, 10: 237-246.

NOOR, M. A. \& AQUADRO, C. F., 1998, Courtship songs of Drosophila pseudoobscura and D. persimilis: analysis of variation. Anim. Behav., 56: 115-125.

RITCHIE, M. G. \& GLEASON, J. M., 1995, Rapid evolution of courtship song pattern in Drosophila willistoni species. J. Evol. Biol., 8: 463-479.

RITCHIE, M. G. \& KYRIACOU, C. P., 1996, Artificial selection for a courtship signal in Drosophila melanogaster. Anim. Behav., 52: 603-611.

RITCHIE, M. G., YATE, V. H. \& KYRIACOU, C. P., 1994, Genetic variability of the interpulse interval of courtship song among some European populations of Drosophila melanogaster. Heredity, 72: 459-464.

SCHILCHER, F. V., 1976, The role of auditory stimuli in the courtship of Drosophila melanogaster. Anim. Behav., 24: 18-26.

SENE, F. M. \& MANFRIN, M. H., 1998, A chamber to record the courtship song in Drosophila. D. I. S., 81: 203-204.

SHOREY, H. H., 1962, The nature of the sound produced by Drosophila melanogaster during courtship. Science, 137: 677-678.

TIDON-SKLORZ, R. \& SENE, F. M., 1992, Vertical and temporal distribution of Drosophila (Diptera, Drosophilidae) species in a wooded area in the state of São Paulo, Brazil. Rev. Brasil. Biol., 52: 311-317.

TOMARU, M. \& OGUMA, Y., 1994, Differences in courtship song in the species of the Drosophila auraria complex. Anim. Behav., 47: 133-140.

VANZOLINI, P. E., 1981, A quasi-historical approach to the natural history of the differentiation of reptiles in tropical geographic isolates. Papeis Avulsos Zool., 34: 189.

VILELA, C. R., 1983, A revision of the Drosophila repleta species group (Diptera, Drosophilidae). Revta. Bras. Ent., 27: $1-114$.

VILELA, C. R., PEREIRA, M. A. Q. R. \& SENE, F. M., 1983, Preliminary data on the geographical distribution of Drosophila species within morphoclimatic domains of Brazil. II. The repleta group. Cienc. Cult., 35: 66-70.

WASSERMAN, M., 1962, Cytological studies of the repleta group of the genus Drosophila. VI. The fasciola subgroup. Univ. Texas Public., 6205: 119-134. 
WASSERMAN, M., 1982, Evolution of the repleta group. In: M. Ashburner, H. L. Carson \& J. N. Thompson (eds.), The genetics and biology of Drosophila, vol. $3 \mathrm{~b}$. Academic Press, London, pp. 61-139.

WASSERMAN, M., 1992, Cytological evolution of the Drosophila repleta species group: VI. The fasciola subgrupo. In: Studies in Genetics II. Research Reports on Drosophila genetics, taxonomy and evolution. CRC Press, Inc., M. R. the University of Texas, Austin.
WELBERGEN, P., VAN DUKEN, F. R., SCHARLOO, W. \& KÖHLER, W., 1992, The genetic basis of sexual isolation between Drosophila melanogaster and D. simulans. Evolution, 46: 1385-1398.

WHEELER, D. A., FIELDS, W. L. \& HALL, J. C., 1988, Spectral analysis of Drosophila courtship songs: $D$. melanogaster, D. simulans, and their interspecific hybrid. Behav. Genet., 18: 675-703. 